\title{
Abrasion effects on microbes in sandy sediments
}

\author{
Douglas C. Miller* \\ School of Oceanography, WB-10, University of Washington, Seattle, Washington 98195, USA
}

\begin{abstract}
In laboratory experiments in an annular flume, high rates of bedload transport significantly reduced epipsammic bacterial and diatom abundances. During abrasion, microbial abundances declined exponentially to an asymptote representing populations of microbes protected in concave areas on grain surfaces. The statistical distributions of microbial counts per unit area of grain surface reflected this decline in abundance and change in spatial distribution. Late-winter, storm-induced transport events at a site in False Bay, Washington, USA, caused no decrease in microbial abundances, but estimated transport rates were low compared to those resulting in abrasion in laboratory experiments. Examination of these results in light of published models and measured sediment transport rates indicated that characteristics of the transport regime, such as grain speed, sediment concentration, and depth of the moving layer, must be measured to relate sediment transport rate to abrasion rate. High transport rates such as those producing significant abrasion in laboratory experiments are common in open-coast surf zones and on continental shelves during storms.
\end{abstract}

\section{INTRODUCTION}

Abrasion is a common explanation for the spatial and temporal variations in epipsammic microbial abundances observed in the field (Meadows \& Anderson 1968, Steele \& Baird 1968, Steele et al. 1970, Munro et al. 1978, Weise \& Rheinheimer 1978, DeFlaun \& Mayer 1983, de Jonge 1985, de Jonge \& van der Bergs 1987). For example, Munro et al. (1978) reported that abrasion removed much of the epipsammic microbial production from sands in the swash zone of Indian beaches. The significance of abrasion on epipsammic microbes may be largely episodic as in large, ablative storm events following periods favorable for microbial growth and accumulation of biomass. On a longer time scale, abrasion may be an important cause of the decrease in microbial standing stock seen in the fall season and may maintain low abundances throughout the winter (DeFlaun \& Mayer 1983). There is much recent evidence which indicates that sediment dynamics affects microbial abundance over a wide spectrum of spatial and temporal scales (de Jonge 1985, Grant et al. 1986, Plante et al. 1986). However, the importance of abrasion relative to other factors is difficult to determine in the field because sediment transport patterns typically covary throughout the year with other environmental

\footnotetext{
- Present address: College of Marine Studies, University of Delaware, Lewes, Delaware 19958, USA
}

and biological factors known to be correlated with microbial biomass or production (e.g. Nowell et al. 1981. Cammen 1982, Grant et al. 1982, Höpner \& Wonneberger 1985, Cammen \& Walker 1986, Grant 1986, Lukatelich \& McComb 1986, Plante-Cuny \& Bodoy 1987, Fielding et al. 1988, Shaffer 1988, Sundbäck \& Jönsson 1988).

Removal of microbes by abrasion should be most important in field situations of high transport rates where grain-grain interactions resist the shear of the transporting fluid (Bagnold 1954, 1956, 1966). Based on analogy with molecular collisions in second-order chemical reactions, Miller et al. (1984) predict that microbial abrasion rate should scale as the square of the transport rate. Given enough energy, abrasion can decrease epipsammic microbial abundances within minutes. Indeed, homogenization of sediments in a blender is a common way of removing bacteria from sediment surfaces for epifluorescence enumeration.

In this paper I address 2 questions. First, what rates and periods of sediment transport will significantly decrease microbial populations on fine sandy sediments? Second, what is the effect of late winter storm sediment transport events on microbial abundances in the field? Because of the difficulty in controlling experimental conditions in the field, I used a laboratory annular flume used to simulate transport events. Bacteria and diatoms were counted directly on the grains themselves using a modification of the acridine orange 
direct count method (Hobbie et al. 1977). Results from these experiments were compared with results from examination of samples from a field site, and with literature data on flow and sediment transport conditions at this and other sites.

\section{METHODS}

Annular flume experiment. Fine sand from waveformed ripples was collected on 20 March 1985 from the crest of a $10 \mathrm{~cm}$ high sandbar at $+1.3 \mathrm{~m}$ above mean low water (i.e. approximately at the mean water level) at a site in False Bay $\left(48^{\circ} 29^{\prime} \mathrm{N}_{\mathrm{i}} 123^{\circ} 04^{\prime} \mathrm{W}\right)$, San Juan Island, Washington, USA. This site was also used for measurements of sediment transport in October 1984 (Miller \& Sternberg 1988). At nearby Friday Harbor Laboratories, ca 11 of this sand (median grain size, $167 \mu \mathrm{m} ; 8 \%$ silt) was placed in the annular flume described in Taghon et al. (1984). The circular sediment channel is $10.5 \mathrm{~cm}$ wide and $158 \mathrm{~cm}$ in inside diameter, and contained 621 of seawater. Flow in the channel is driven by a rotating ring forming the top surface of the sediment channel (water depth, $11.2 \mathrm{~cm}$ ). This ring is turned by a horizontal bar connected to a motor with rotation rate variable from 0 to more than 20 rotations $\mathrm{min}^{-1}$. The annular design allowed transport of sediment around an indefinitely long flume without introducing fluid shear or abrasion artifacts associated with a pumping mechanism. Hose outlets at the level of the drive ring allowed fresh seawater to exchange continuously through the sediment channel at a rate of about $1.81 \mathrm{~min}^{-1}$. This exchange (a turnover time of $35 \mathrm{~min}$ ) maintained a temperature of 8 to $10^{\circ} \mathrm{C}$ in the flume, no higher than $3 \mathrm{C}^{\circ}$ above that of the seawater supply into the laboratory building

The curvature of the sediment channel introduces a secondary circulation in the flow: outward at the top, where the velocity (and hence the centrifugal force) is the greatest, and inward flow at the bottom. The resulting distribution of bottom shear stress caused the sediment to deposit in the inside corner of the channel, forming (in cross section) a roughly triangular wedge $2 \mathrm{~cm}$ wide and $1 \mathrm{~cm}$ deep. Arcuate ripples $10 \mathrm{~cm}$ along the ripple crest and $0.5 \mathrm{~cm}$ high at an angle of $50^{\circ}$ to the channel (i.e. oriented across the direction of the local bottom stress) migrate downstream as the top layer of this sediment wedge. Particle movement in these ripples was observed to be the same as that in 2 dimensional, unidirectional-flow ripples: grains hop up the stoss (upstream) side of the ripple and are buried at the base of the lee face.

The flume was run at a high rotation rate for about $1 \mathrm{~h}$ to disperse the sediment around the flume and to form migrating ripples. After these ripples had formed uniformly around the flume, the ring rotation rate was decreased just to the point at which sediment ceased to move (10.3 rotations $\mathrm{min}^{-1}$ ). Tangential ring velocities cannot be used to estimate imposed bed stresses since friction factors have not been determined for this apparatus or sediment transport regime. A stationarybed condition (i.e. no movement of sand grains) was maintained for the next $23 \mathrm{~h}$. Samples of the sediment prior to putting it in the flume, and at 12 and $24 \mathrm{~h}$ after the start of the experiment, were taken by temporarily stopping and removing the ring, and scooping about $0.5 \mathrm{ml}$ of sediment from the middle of a ripple crest (top $2 \mathrm{~mm}$ ) with a spatula. The sediment was transferred to a sterile test tube and fixed immediately with $0.2 \mu \mathrm{m}$ sterile-filtered, $2 \%$ formaldehyde in seawater. This sampling method collected only those grains subject to transport during transport events. The small wedge of sediment stationary at the inside edge of the channel was not sampled by this method.

The abrasion experiment consisted of 2 sediment transport events (denoted 'Rippled-Bed' and 'PlaneBed' regimes) each followed by a stationary-bed, recolonization period ('Stationary-Bed [1]' and '[2]', respectively) at flow strengths just below that needed to transport the sediment. Specifically, after the 24 h sediment sample was taken, the ring rotation rate was increased to $14.9 \mathrm{~min}^{-1}$, which caused sediment to transport in ripples as described above. Subsequently, sediment samples were taken at $2 \mathrm{~h}$ intervals for the next $8 \mathrm{~h}$ ( 26 to $32 \mathrm{~h}$ after the start of the experiment). Rotation rate was then decreased $\left(8.2 \mathrm{~min}^{-1}\right)$ to below that needed for transport to occur. Sediment samples were taken over the next $4 \mathrm{~d}$ at $24 \mathrm{~h}$ intervals (56 to $128 \mathrm{~h})$. At $140 \mathrm{~h}$, a sample was taken, and the ring rotation rate was increased $\left(21.2 \mathrm{~min}^{-1}\right)$ to cause sediment to move in plane-bed transport regime (i.e. grains moving in a 'carpet' without forming ripples or other bedforms), with the finer fraction of the sediment transporting in suspension. Sediment samples were taken from the top $2 \mathrm{~mm}$ of sediment (at a haphazard location) at $8 \mathrm{~h}$ intervals for $3 \mathrm{~d}$ (148 to $196 \mathrm{~h}$ ). Another stationary-bed, non-transport period followed (rotation rate, $10.3 \mathrm{~min}^{-1}$ ) with samples taken at $24 \mathrm{~h}$ intervals (220 to $292 \mathrm{~h}$ )

Field samples and sediment transport estimates. Samples for assessment of field microbial abundances at False Bay were taken from crests of wave-formed ripples (wavelength 7 to $8 \mathrm{~cm}$, height 1 to $1.5 \mathrm{~cm}$ ) from the bar crest within a meter of the instrument site used by Miller \& Sternberg (1988). Obvious feeding traces and fecal material from lugworms Abarenicola pacifica, tellinid clams Macoma nasuta and spionid polychaetes (primarily Pseudopolydora kempi japonica) were avoided. These samples were preserved as described above for the flume samples. They were taken every 
other day on the mid-day low tide from 20 March to 1 April 1985. Weather information for this time period was obtained from the files of the National Weather Service office in Seattle. Miller \& Sternberg (1988) correlated wind reports for October 1984 from the Race Rocks Lightstation in the Strait of Juan de Fuca with flow and sediment transport parameters measured over $4 \mathrm{~d}$ at the field site. In a resulting empirical equation for scalar, vertically-integrated transport rate, $q_{\mathrm{s}}$ is proportional to wind speed $W\left[\mathrm{~km} \mathrm{~h}^{-1}\right]$ above a threshold: $q_{\mathrm{s}}\left[\mathrm{g} \mathrm{cm}^{-1} \mathrm{~s}^{-1}\right]=7.5 \times 10^{-4} \times(W-6.3), W \geq 6.3 \mathrm{~km} \mathrm{~h}^{-1}$, $\left.N=50, R^{2}=0.26\right)$. This equation and interpolated wind speeds from Race Rocks ( $3 \mathrm{~h}$ report intervals) were used to predict the amount of sediment transport every $14 \mathrm{~min}$ (i.e. 100 times per day) during periods of immersion at the field site over the sampling interval. Water levels were based on a least squares fit of 3 semidiurnal, 3 diurnal, a lunar fortnightly, and a lunar monthly tidal components to predicted times of high and low water at Kanaka Bay, San Juan Island, $1 \mathrm{~km}$ west of False Bay (based on tabulated values in N.O.A.A. 1984).

Microbial enumeration by acridine orange direct counts and statistical methods. Bacteria and diatoms were counted by the technique of Hobbie et al. (1977) modified to obtain counts directly from grain surfaces. Laboratory flume and field samples were processed within $12 \mathrm{~d}$. Grains were stained $2 \mathrm{~min}$ with a $0.01 \%$ acridine orange solution, filtered onto a pre-blackened (Sartorius), cellulose acetate, $0.65 \mu \mathrm{m}$ filter and mounted on a glass slide with immersion oil. The stained sediment was examined under epifluorescence illumination at $1250 \times$ using a Zeiss Photomicroscope with a III RS epifluorescence condenser (with blue interference exciter filters, $510 \mathrm{~nm}$ chromatic beam splitter, and $520 \mathrm{~nm}$ orange barrier filter) and a $100 \mathrm{~W}$ halogen lamp. Stained samples were kept in the dark and counted within $5 \mathrm{~h}$ of preparation. Counts of microbes on 40 grains were started by locating haphazardly in the field of view a grain near the edge of the filter. This grain was positioned such that its extreme right edge coincided with the right-center edge of the eyepiece grid. All bacteria and diatoms (predominantly pennate) in the lower-left quadrant of the eyepiece grid were counted, representing a grain-surface projected area of $38 \mu \mathrm{m} \times 38 \mu \mathrm{m}=1444 \mu \mathrm{m}^{2}$. This protocol effectively samples only those grains larger than about $100 \mu \mathrm{m}$, that is, in the fine sand and larger size ranges. I did not count cells on those occasional grains which did not completely fill the counting quadrant. Substantial adjustment of the fine focus was required to view the entire grain surface within the counting quadrant. Counting required about 1 min per grain during which cell fluorescence did not fade noticeably. Subsequent grains were located systematically by moving in one direction (left or right), reversing the direction when the edge of the sediment sample was encountered, and offsetting the counting swath slightly to avoid recounting grains. The newly selected grain was positioned in the field of view and counted as described above. Blanks indicated no contamination of epipsammic counts. All microbial counts generated in this study are available in an appendix to Miller (1985).

A priori, I expected bacterial and diatom abundances on sand grains to decrease during periods of transport (24 to $32 \mathrm{~h}$ and 140 to $196 \mathrm{~h}$ ), and to increase during stationary-bed, zero-transport periods (32 to $140 \mathrm{~h}$ and 196 to 292 h). As a statistical test, I used a non-parametric test for the null hypothesis of no difference in abundance in each microbial taxon among sediment samples against the alternative of a trend in abundance in a specified direction (Jonckheere ordered alternatives test, Hollander \& Wolfe 1973). The test statistic used, $J^{*}$, is that for the large sample approximation and is asymptotically distributed as the standard normal distribution. An error rate of $\alpha=0.05$ was used for each test to determine statistical significance. The test results reported are conservative since they are not adjusted for the presence of ties in the data (Hollander $\&$ Wolfe 1973). Cumulative distribution plots (Chambers et al. 1983) of the bacterial counts on the grains were used to compare spatial distributions of bacteria on unabraded, abraded, and recolonized grains.

\section{RESULTS}

\section{Flume experiment}

\section{Bacterial abundances}

The time series of bacterial abundances and experimental conditions over the course of the laboratory annular flume experiment are depicted in Fig. 1. Results of statistical tests for trends in microbial abundance are presented in Table 1. Bacterial abundances decreased suggestively, but not significantly during the first, rippled-bed transport event. For this period, the transport rate may be estimated from the ripple migration rate. A mean ripple turnover time of about 2 min for a $2.5 \mathrm{~cm}^{3}$ ripple (width $2.5 \mathrm{~cm}$, bulk density of sand $1.5 \mathrm{~g} \mathrm{~cm}^{-3}$ ) corresponds to a bedload transport rate of $1.2 \times 10^{-2} \mathrm{~g} \mathrm{~cm}^{-1} \mathrm{~s}^{-1}$. Thus, transport on a rippled bed at a rate of order $10^{-2} \mathrm{~g} \mathrm{~cm}^{-1} \mathrm{~s}^{-1}$ for $8 \mathrm{~h}$ resulted in no detectable decrease in microbial abundances. Bacterial abundances subsequently increased significantly in the first recolonization period.

During the second, plane-bed transport event, bacterial abundances decreased significantly about $30 \%$ in the first $16 \mathrm{~h}$ and thereafter remained relatively 
Table 1. Results of tests for trend in microbial abundances. Microbial abundances are per $1444 \mu \mathrm{m}^{2}$ projected area. Tests for hypothesized increasing or decreasing trends in microbial abundance are each based on a series of 5 to 8 samples, each with 40 separate grain counts. Asterisks indicate the significance of the test result: ${ }^{*} p<0.05$ or $\cdots p<0.01$

\begin{tabular}{|c|c|c|c|c|}
\hline & \multicolumn{4}{|c|}{ Transport characteristics and samples } \\
\hline & Ripple transport & Stationary bed (1) & Plane-bed transport & Stationary bed (2) \\
\hline Hypothesized trend & Decrease & Increase & Decrease & Increase \\
\hline Sample series & $24-32 \mathrm{~h}$ & $32-140 \mathrm{~h}$ & $140-196 \mathrm{~h}$ & $196-292 \mathrm{~h}$ \\
\hline No, of samples & 5 & 6 & 8 & 5 \\
\hline \multicolumn{5}{|l|}{ Bacteria } \\
\hline Test statistic, $J^{\bullet}$ & 1.38 & $2.27^{\circ}$ & $3.00^{\cdots}$ & 1.56 \\
\hline Probability & 0.084 & 0.012 & 0.0013 & 0.059 \\
\hline \multicolumn{5}{|l|}{ Diatoms } \\
\hline Test statistic $J^{\bullet}$ & -0.54 & 0.65 & $2.46^{*}$ & $2.11^{\circ}$ \\
\hline Probability & 0.70 & 0.26 & 0.0069 & 0.017 \\
\hline
\end{tabular}

constant (Fig. 1). There was a marginally non-significant increase in bacterial abundance in the second recolonization period. Cumulative distribution plots for the bacterial data (Fig. 2) indicated that unabraded (140 h sample) and recolonized grains (292 h) had approximately normally-distributed bacterial counts las can be demonstrated using a Kolmogorov-Smirnov 1 -sample, intrinsic hypothesis test, $p>0.20$, Sokal \& Rohlf 1981). Abraded grains yielded counts with lower minimum and maximum values, and a higher proportion of zero- or low-numbered cell counts. This results in the skewed, comparatively J-shaped cumulative distribution plots (e.g. $196 \mathrm{~h}$ sample versus normal distribution, intrinsic hypothesis test, $p=0.035$; or 196 h sample cf. 140 h sample, in Fig. 2, yielding a 2tailed $p=0.026$ by 2 -sample Kolmogorov-Smirnow test; Sokal \& Rohlf 1981). Lower counts occurred primarily on the outer surfaces of the grains: these regions under epifluorescence illumination appeared as large, dark areas devoid of microbes and lacking the typical orange appearance of stained organic matter on sediment surfaces. Crevices and hollows supported large numbers of bacteria and diatoms in the organic matrix even on well-abraded grains. On recolonized (or unabraded) grains the orange matrix covered nearly the entire grain surface with microbes on outer as well as concave surfaces. The change in distribution of counts reflected the change in distribution of bacteria on the particles (Fig. 2). After recolonization, count distributions were again approximately normally distributed. By the end of the experiment, the sediment in the flume had become coarser with a median grain size $277 \mu \mathrm{m}, 4 \%$ silt, with the loss of material occurring primarily in the $<250 \mu \mathrm{m}$ fraction.

\section{Diatom abundances}

During the first $24 \mathrm{~h}$ of the experiment diatom abundances increased substantially (Fig. 1). Diatoms con-

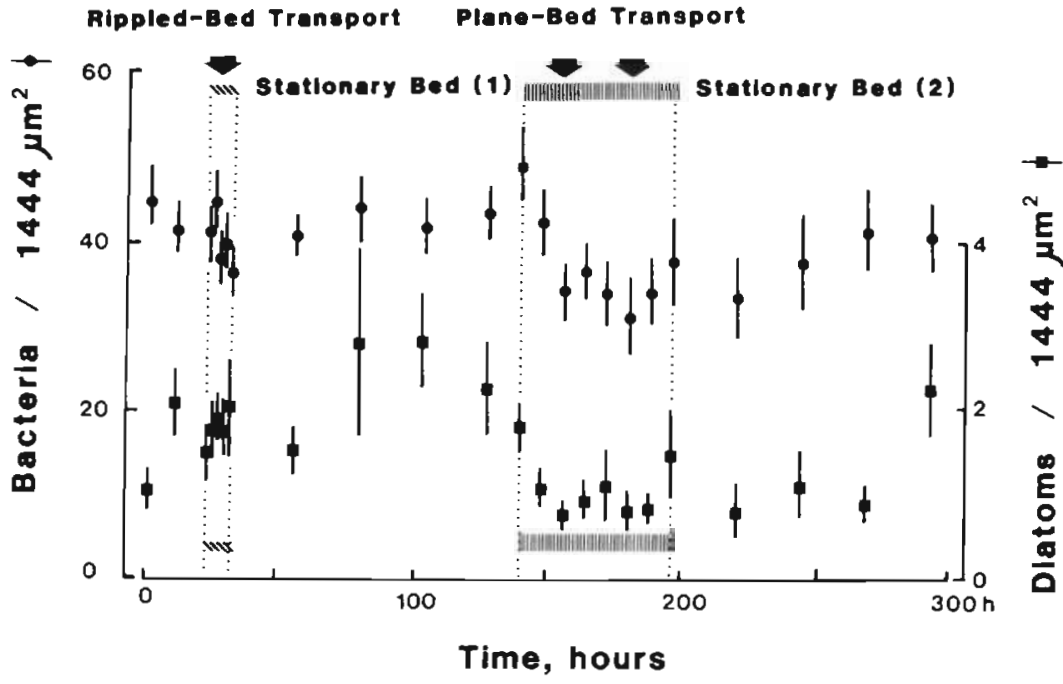

Fig. 1. Epipsammic bacteria (•) and diatom (a) abundances over the course of the annular flume abrasion experiment. Abundances are plotted as mean plus or minus standard error of the mean based on sample of 40 grains 
Fig. 2. Empirical, cumulative distribution plots of bacterial counts $(n=40)$ for 140 to 292 h samples from the annular flume experiment. Ordinate: sample bacterial count; abscissa: normal probability scale, staggered by sample time (i.e. $8 \mathrm{~h}$ each for 149 to $196 \mathrm{~h}$ samples, thereafter by $24 \mathrm{~h}$ each for 196 to 292 h samples). Normally distributed counts plot as straight lines on this horizontal scale

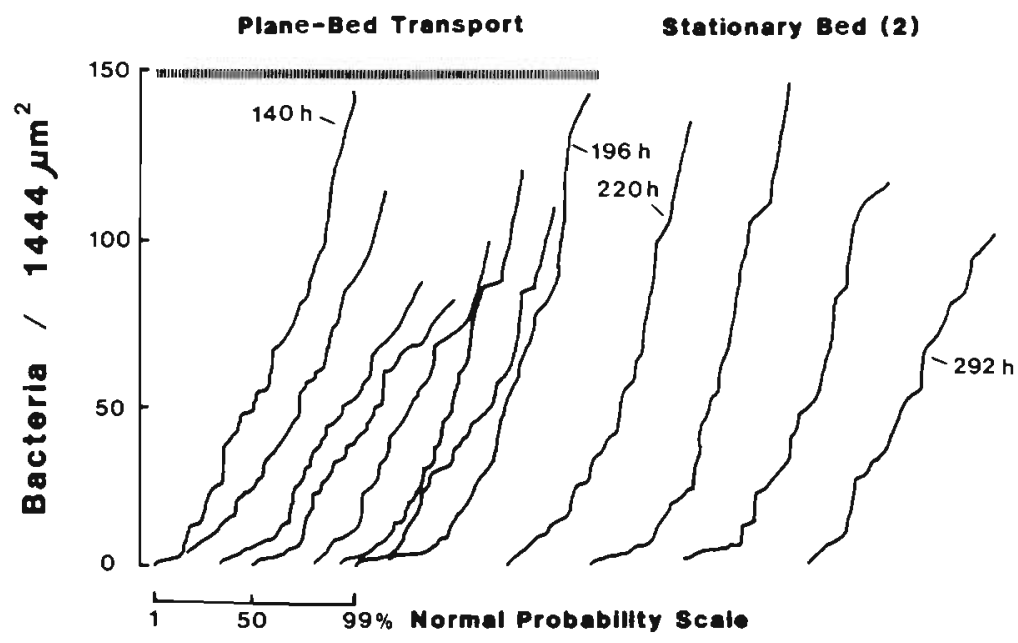

tinued to increase (though not significantly) during the first transport and recolonization periods (Table 1). Diatom abundance significantly decreased during the first $16 \mathrm{~h}$ of the plane-bed transport event and remained low until increasing in the recolonization period. Increases in diatom abundance were visible as a browning of the sediment surface during recolonization periods. Overall trends in diatom abundance are harder to interpret than those in bacterial abundances. Laboratory sample standard deviations varied widely from sample to sample, in part due to the formation of large diatom colonies. Examination of the raw count data reveals that large counts (i.e. large relative to the mean expected abundance) from single grains greatly affected the sample means and variances. The most extreme example of this effect occurred in the $80 \mathrm{~h}$ sample (Fig. 1): a count of 44 diatoms in a single colony substantially increased the sample mean and variance otherwise composed of grains with zero to 7 diatoms (per $1444 \mu^{2}$ ) each.

\section{Field results}

Prior to the field sampling at False Bay (i.e. 18 to 20 March), winds were light at less than 12 knots. On 20 March ( 0 h field sample), a brown diatom film was apparent on the sediment surface. False Bay supports populations of motile diatoms (Pamatmat 1968, Rao \& Lewin 1976, Miller \& Sternberg 1988) apparent as brown patches on ripple crests and troughs easily visible on overcast, but not sunny days. During the next $10 \mathrm{~d}$, weather was variable with 2 distinct storm events (winds in excess of 20 knots) on 22 to 23 and 29 March; high winds also occurred on 26 March but at a time when the site was emersed. Fig. 3 is the time series of bacterial and diatom abundances at the site with

\section{Cumulative Distribution of Counts}

stormy and calm (zero estimated sediment transport, winds less that $6.3 \mathrm{~km} \mathrm{~h}^{-1}$ ) periods indicated. No substantial decrease in abundance is associated with either storm event. Microbial abundances remained fairly constant over the series (with some evidence for an increasing trend in bacterial abundances, ordered alternatives test $J^{*}=2.22, p=0.028$ ), and at levels typical of unabraded grains in laboratory experiments (cf. Fig. 1). Variances in microbial abundances, particularly diatoms, were more consistent in field than laboratory samples. Further, field-sampled grains yielded bacterial counts that were normally distributed, similar to those of laboratory unabraded and recolonized grains (as in Fig. 2). These storms were similar to those observed in October 1984 (Miller \& Sternberg 1988 ) to cause frequent sediment transport events at the same site. During the field sampling, periods of tidal immersion shifted (on $25 \mathrm{March}$ ) from two 5 to $6 \mathrm{~h}$ periods per day to a single period of about $15 \mathrm{~h}$. Gross (oscillatory) bedload transport rates of 1 to $3 \times 10^{-2} \mathrm{~g}$ $\mathrm{cm}^{-1} \mathrm{~s}^{-1}$ were estimated for the 2 storms; Miller \& Sternberg (1988) concluded that scalar transport rates of this order occurred often and throughout the year at False Bay. Further statistical analysis revealed no evidence for a linear correlation between the change in bacterial or diatom abundance between samples and the total amount of sediment transport (summed over immersed periods, and calculated as the mean transport rate times the immersion period) between field samples since correlation coefficients were positive, not less than zero as anticipated.

\section{DISCUSSION}

The pattern of abrasion of microbes from sand grains described here is the same as that reported by Meadows 


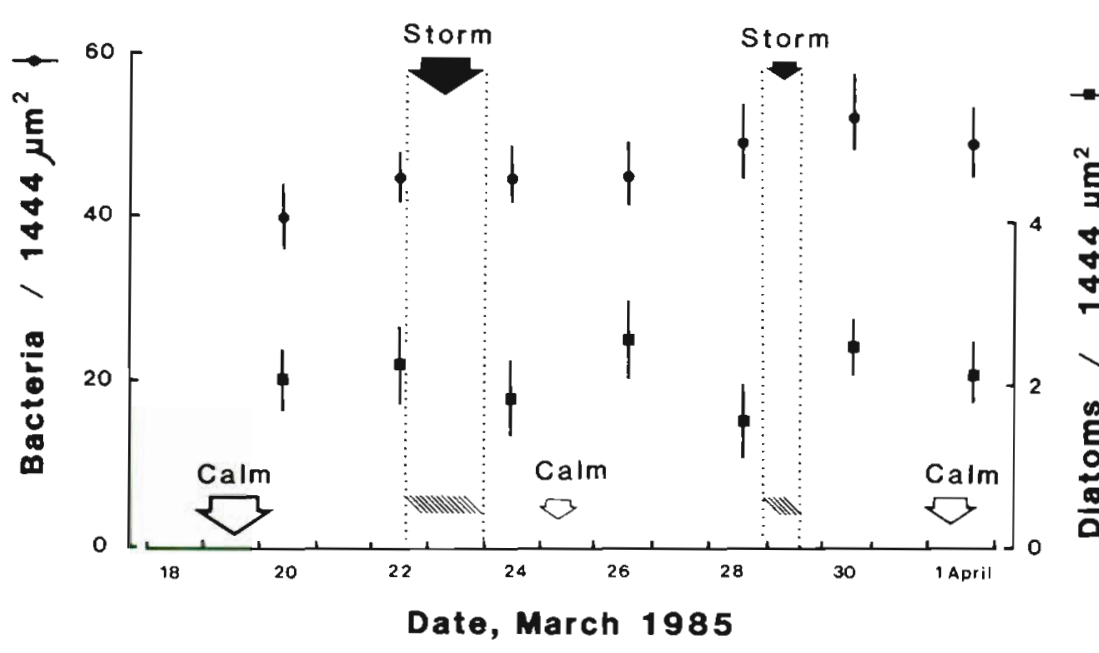

Fig. 3. Field bacterial $(\bullet)$ and diatom ( abundances at False Bay, Washington, USA, for 19 March to 1 April 1985, plotted as mean plus or minus standard deviation of the mean $\{n=40\}$. Storm and calm conditions during sampling are indicated. Correlation analysis revealed no relationship between changes in microbial abundance and sediment transport (estimated from wind reports, see text) between sampling dates
\& Anderson (1968), Weise \& Rheinheimer (1978) and DeFlaun \& Mayer (1983). Large areas of the abraded grain are bare; epipsammic microflora are concentrated in concave regions. Meadows \& Anderson (1968) demonstrated that this distribution can result from experimental abrasion in a shaker table for 20 min per day for $4 \mathrm{wk}$, though extrapolation from this form of mechanical abrasion to sediment transport is difficult. Weise \& Rheinheimer (1978) found that sand from a wave-exposed site in the Kiel Bight (FR Germany) had a similar pattern of colonization. DeFlaun \& Mayer (1983) examined laboratory-incubated sediments and observed, in contrast to field-sampled sediments, bacterial colonization of exposed and convex grain surfaces. Results of the laboratory annular flume experiment in this study demonstrated that stresses high enough to cause plane-bed transport removed $30 \%$ of the bacteria in $16 \mathrm{~h}$, after which bacterial abundances remained constant. This, however, occurred during the second transport event, after significant growth on grain surfaces in the laboratory. The extent to which this recolonized community is different from the original field community in composition (Stevenson 1986) or susceptibility to abrasion (Charters et al. 1973, de Jonge 1985. Tanaka 1986, de Jonge \& van der Bergs 1987) is not known. The decrease in bacterial abundance for the 0 to 12 h period samples may have resulted from operating the flume at high transport rate to distribute the sand evenly around the flume at the start of the experiment. Bacterial recolonization rates (increase in cell numbers per time, here of order 10 cells per $1444 \mu^{2}$ in $100 h_{1}$ ) in the annular flume experiment were similar to those reported in other studies at Friday Harbor Laboratories by Eckman (1985) on plastic fibers and by Miller (unpubl.) on sterilized coverglasses in the same flume used by Eckman (1985).

The observed increase in diatom abundance in the first $24 \mathrm{~h}$ of the experiments (Fig. 1) may have rep- resented the movement of motile diatoms to the sediment surface from below. Sand placed in the flume was taken from ripples in the field and hence was a mixture of surface and subsurface (to $1 \mathrm{~cm}$ depth) field sediment. Light conditions in the laboratory during the annular flume experiment and lack of tidal cycles in flow and immersion may explain the initial trends in the diatom abundance time series.

Meiofauna (nematodes, turbellarians, harpacticoid copepods, and gastrotrichs) were abundant in the flume at the beginning of the experiment but not in the sediment samples following the transport events. Median sediment grain size in the annular flume increased during the second transport event. This, however, does not bias the present results since bacteria and diatoms were reported on a projected-area basis. Recolonization and the spatial distribution of microbes on grain surfaces in the flume (Figs. 1 and 2) are not readily explained by grazing or changes in grain roughness with median grain size. Obscuring of cells by organic coatings on the particle (more prevalent on unabraded particles) would cause an underestimate of the effect of abrasion.

Bacterial abundances found in the field and laboratory experiments were 4 to $6 \times 10^{8} \mathrm{~g}^{-1}$ (converted from projected area to weight basis for a grain size of $167 \mu \mathrm{m})$. These abundances are lower, but of the same order, as those reported for sandy sediments (e.g. Dale 1974, Meyer-Reil et al. 1978, Montagna 1982). Field samples taken during a sedimentologically active period at False Bay showed no evidence that exposed microbial populations were reduced during storm sediment transport events. Estimated transport rates at False Bay were of the same order $\left(10^{-2} \mathrm{~g} \mathrm{~cm}^{-1} \mathrm{~s}^{-1}\right)$ and approximate duration $(6 \mathrm{~h})$ as the first, rippled-bed transport event in the annular flume experiment in which no significant abrasion was observed. Thus, these field data corroborate the rippled-bed laboratory 
flume experiment results. Advection of sediments (via net transport and wave mixing) from the relatively protected bar troughs landward or seaward of the sampling site on the bar crest, or erosion and exposure of local subsurface sediments, could have supplied grains with high microbial abundance to the sampling site. However, there is no evidence for net erosion or deposition at the site over the sampling interval. Storms and associated sediment transport events are apparently not factors controlling microbial populations in the high intertidal zone at False Bay during the late winter.

\section{Abrasion as a first-order linear process}

The pattern of an exponential decrease in epipsammic abundances resulting from constant sediment transport conditions can be explained by the following simple model of a first-order linear rate process. Grainbed and grain-grain collisions remove bacteria from exposed surfaces, while significant populations persist in protected, concave areas on grain surfaces. If each collision removes microbes from an exposed area on the grain (or does so with some probability), then the rate of decrease in the exposed population will be proportional to that population size and per-grain collision frequency. The total population $(N)$ is equal to the sum of the exposed $\left(N_{\mathrm{e}}\right)$ and the protected $\left(N_{\mathrm{p}}\right)$ populations, and the rate of decrease of the total population is proportional to the difference between the total and protected sub-population sizes. Written as a differential equation, this is

$$
\mathrm{d} N / \mathrm{d} t=-\alpha \cdot\left(N-N_{\mathrm{p}}\right)
$$

where $\alpha=$ the proportionality constant, the specific abrasion rate (dimensions of time ${ }^{-1}$ ). The solution to Eq. (1) is:

$$
N(t)=N_{0} \exp (-\alpha t)+N_{\mathrm{p}} \cdot(1-\exp [-\alpha t])
$$

where $N_{0}=$ initial (total) population abundance.

Eq. (2) describes an exponential decrease in population abundance: a linear decline at first, followed by a slow approach to the steady-state, protected population abundance. For the plane-bed transport event in the annular flume experiment, this model was fitted to the observed mean abundances for bacteria and diatoms (indicated by symbols in Fig. 1) using a non-linear, least-squares technique. For the significant decreases found in the plane-bed transport period, best-fit values for the initial and protected populations were 49 and 34 (bacteria) and 1.8 and 1.0 (diatoms) per $14.44 \mu \mathrm{m}^{2}$. Abrasion coefficients were $0.11 \mathrm{~h}^{-1}$ (bacteria) and $0.34 \mathrm{~h}^{-1}$ (diatoms) with 84 and $59 \%$ of the variation in mean abundance (respectively) explained by the fit.
Eq. (2) assumes that the protected population size is constant at all abrasion rates, although it seems likely that more of the grains' surface will be susceptible to abrasion when collisions are more energetic (e.g. occurring at higher speed or between bigger grains). The total microbial abundances observed results from the balance of abrasion and population growth via in situ cell divison and settlement. Therefore, this abrasion parameter represents net effect of abrasion and growth for microbial populations on exposed surfaces. Observed rates of decrease (about 15 bacteria per $1444 \mu^{2}$ in $16 \mathrm{~h}$ ) are much higher than recolonization rates observed here and in other experiments at Friday Harbor Laboratories (see above, Eckman 1985, Miller unpubl.). Thus recolonization does not appreciably bias the estimated abrasion rate for the exposed microbial populations. This simple model cannot account for the upward trend in the upper tails of the cumulative distribution plots (Fig. 2), and to some extent in mean abundances (Fig. 1), of samples from the latter part of the plane-bed transport event, suggesting that the protected population may increase even while cells are being removed from exposed regions of the grains.

\section{Abrasion as a function of transport rate and regime}

At the high bed load transport rates over a plane bed, grains collide not only with the bed, but also with one another in the moving layer of sediment. Frequency of grain-grain collisions (aside from those with the bed) in a volume element in the transporting layer is proportional to the square of concentration of grains in the that layer. Collisions occur at a rate proportional to the turbulent, collision-producing, velocity fluctuations of the particles. In equation form, take $C$ as the grain concentration (number per volume) and $\left\langle u^{\prime}\right\rangle$ as a measure of the velocity fluctuations:

$$
\text { Total Collision Rate } \sim<u^{\prime}>C^{2}
$$

Total transport rate is the mass concentration of sediment in the layer $C_{g}$ times the mean downstream speed of grains in the layer $U_{g}$ times the height of the layer $H$ (since bedload rates are vertically integrated fluxes):

$$
q_{\mathrm{s}}=C_{\mathrm{g}} \cdot U_{\mathrm{g}} \cdot H
$$

As a working hypothesis, assume that turbulent velocity fluctuations $\left\langle u^{\prime}\right\rangle$ in the transport layer are proportional to the grain speed $U_{g}$. A comparison of Eqs. (3) and (4) indicates that total collision rate will scale as the square of grain concentration for a given speed, but that its relationship with transport rate will be determined by how grain speed and layer thickness vary with transport rate (substituting Eq. [4] into Eq [3]): 


$$
\begin{gathered}
\text { Total Collision Rate } ~ \\
U_{\mathrm{g}} \cdot\left(q_{\mathrm{s}} / U_{\mathrm{g}} \cdot H\right)^{2} \sim q_{\mathrm{s}}^{2} /\left(\begin{array}{ll}
U_{\mathrm{g}} & H^{2}
\end{array}\right)
\end{gathered}
$$

Both grain speed and layer height would be expected to increase with transport rate. Therefore, total collision rate should scale not quite as the square of transport rate. High transport rates should thus be especially effective at abrading microbes from grain surfaces. The total collision rate divided by the number of grains yields the per-grain collision rate (denoted $\alpha$, above); therefore, specific abrasion rate scales roughly with the transport rate. At very high transport rate and sediment concentrations $10 \%$ sediment by volume; Bagnold 1966), grain-grain collisions produce a force that resists the shear of the driving fluid. This grain-encounter stress, proportional to the normal dispersive grain pressure by a friction coefficient, is a direct measure of the square root of the collision rate in the transporting layer. A useful analogy is that of an ideal gas behavior: pressure on the walls of the gas container is determined by the collision rate with the wall and is proportional to the amount of gas in the container (Froment \& Bischoff 1979). Molecular collision rate in the container scales as the gas concentration squared. Sediment grain size also affects collision rate for a given mass flux. Its effect can be included in the above discussion as a proportionality constant representing the mass of a single grain.

A more detailed, mechanistic model of grain-bed or grain-grain collisions which presumably act to abrade microbes from exposed grain surfaces is possible. Though such a model is not needed to explain the present data, it should guide further experiments. Recent studies of the motion of individual sediment grains and their interactions include: Kobayashi \& Seo (1985), Wiberg \& Smith (1985), Kobayashi \& DeSilva (1987), and Anderson \& Haff (1988). If the molecular collision analogy is correct, then theory of granular material flows is applicable (Bagnold 1954, 1956, 1966, Savage \& Jeffrey 1981, Jenkins \& Savage 1983, Savage \& Sayed 1984, Hanes \& Inman 1985) and may provide a theoretical basis for understanding abrasion in the plane-bed regime.

One can similarly argue that under oscillatory flow, such as that produced by waves in False Bay, abrasion rate per grain should also scale approximately with gross (or scalar) sediment transport rate. Wave-forced bottom shear stresses vary on time scales of about $3 \mathrm{~s}$ (Miller \& Sternberg 1988), short compared to that of abrasion or recolonization. Although the direction of particle transport changes each half wave period, abrasion may be considered as a nearly continuous process. Variations in the intensity of wave action on time scales similar to that of abrasion and recolonization (hours to days), such as occur in the passage of storm events must of course be explicitly considered when predicting their effects.

\section{Abrasion at False Bay and in other environments}

Estimated fluxes in False Bay during winter storm events fall short in terms of magnitude of that needed to significantly decrease microbial abundances in laboratory experiments. Mean gross transport rates were of order $3 \times 10^{-2} \mathrm{~g} \mathrm{~cm}^{-1} \mathrm{~s}^{-1}$ over $15 \mathrm{~h}$ periods during which the tide covered the flat. During this study and that of Miller \& Sternberg (1988), the sediment surface at the field site was always covered with wave-formed, cat's-back ripples, sometimes exhibiting a slight on- or off-shore asymmetry. This is indirect evidence that local maximum bed stresses did not exceed 10 to 20 times that of the critical bed stress for initial motion and extend into the 'breakoff' region (Grant \& Madsen 1982) of plane-bed transport. Seaward of the study site, wave energy (all of which enters through the narrow mouth of the bay) is much more concentrated and subject to much less dissipation. The effects of higher wave activity are evident: sediments are coarser and less well consolidated, and smooth patches (devoid of any bedforms) are often seen on the large bar crests. These patches indicate that bottom stresses reach the breakoff region for ripple existence. Flume experiment results suggest the abrasion may be important locally and at certain times at these more wave-exposed sites.

Beyond this qualitative approach, some rough, quantitative comparisons of field bedload transport measurements and event duration with laboratory results may be made. At a protected and rippled intertidal sandflat in South Carolina (USA), Grant (1983) found net bedload transport associated with tidal currents to reach rates of 1 to $2 \times 10^{-2} \mathrm{~g} \mathrm{~cm}^{-1} \mathrm{~s}^{-1}$ for periods limited by tidal immersion. In False Bay during 1 to $2 \mathrm{~d}$ storms, the magnitude of gross sediment transport was of the same order, 1 to $3 \times 10^{-2} \mathrm{~g} \mathrm{~cm}^{-1} \mathrm{~s}^{-1}$, and similarly limited by period of tidal immersion (Miller \& Sternberg 1988, this study). Sediment transport under these conditions would not be expected to produce significant levels of abrasion. Sediment transport rates measured in subtidal environments are variable, ranging from $10^{-1} \mathrm{~g} \mathrm{~cm}^{-1} \mathrm{~s}^{-1}$ off San Juan I. (Kachel \& Sternberg 1971) to $10^{-3} \mathrm{~g} \mathrm{~cm}^{-1} \mathrm{~s}^{-1}$ in the East China Sea (Sternberg et al. 1985). On the open coast surf zone of Washington, Downing (1983) reports net and shorenormal transport rates of 1 to $10^{-1} \mathrm{~g} \mathrm{~cm}^{-1} \mathrm{~s}^{-1}$ resulting from several daylong storms. Beach \& Sternberg (1988) have found very high longshore rates of order $10 \mathrm{~g} \mathrm{~cm}^{-1} \mathrm{~s}^{-1}$ on the open Oregon (USA) coast. These surf-zone transport rates may be sufficiently great to maintain low bacterial 
throughout the year. Continental shelf environments are subject to seasonal storm transport events on time scales matching those of abrasion and recolonization. Rates of sediment transport can be high due to the combined action of mean and wave-induced currents. Vincent et al. (1982) calculated maximum bedload rates during storms in Long Island Sound (USA) of $1 \mathrm{~g}$ $\mathrm{cm}^{-1} \mathrm{~s}^{-1}$; Kachel \& Smith (1986) report calculated rates of order $10^{-1} \mathrm{~g} \mathrm{~cm}^{-1} \mathrm{~s}^{-1}$ of silty sands for storm events on the Washington continental shelf. Therefore, abrasion may at certain times be a significant modulator of microbial abundance in sandy shelf sediments.

\section{CONCLUSIONS}

Laboratory flume experiments determined that high rates of bedload sediment transport over a plane bed can significantly decrease epipsammic bacterial and diatom abundances, confirming earlier field observations (Weise \& Rheinheimer 1978) and earlier laboratory results from less natural simulations of sediment transport (Meadows \& Anderson 1968). During abrasion, microbial abundances declined exponentially to an asymptote representing the protected population abundance. For plane-bed transport in either steady or oscillatory flows, the specific abrasion rate should be proportional to the transport rate to a power less than or equal to one. The uncertainty in this exponent results from the expectation that a number of transport characteristics, for example, ripple size or transporting layer height and grain concentration, are not determined uniquely by transport rate. Without data on these transport characteristics, the best gauges of the importance of abrasion are probably the gross transport rate and duration. Laboratory results suggested that transport rates substantially in excess of $10^{-2} \mathrm{~g} \mathrm{~cm}^{-1} \mathrm{~s}^{-1}$ for $8 \mathrm{~h}$ are required for abrasion to be detected by the methods used. Estimated transport rates during late winter storms at False Bay fell below and near this level and produced no decline in field abundances. Transport rates and event periods in excess of $10^{-2} \mathrm{~g} \mathrm{~cm}^{-1} \mathrm{~s}^{-1}$ and $8 \mathrm{~h}$ are common in some benthic environments such as surf zones and on continental shelves during storm events. Results of this study are experimentally testable lower limits on the level of transport needed to abrade significantly epipsammic microbes and the identification of those sediment transport parameters which must be measured to predict more accurately when abrasion is a significant influence on microbial populations in the field.

Acknowledgements. I thank P. A. Jumars, D. L. Penry, A. R. M. Nowell, R. R. Strathmann, N. Kobayashi, A. J. Ray, and especially R. W. Sternberg for their comments and advice.
This work was made possible through the courtesy of the Director and staff of Friday Harbor Laboratories, support by NSF Grant OCE-86-08157 to P. Jumars and A. Nowell, and by an award from the Seattle Chapter of the Achievement Rewards for College Scientists Foundation. It is Contribution No. 1805 from the School of Oceanography, University of Washington

\section{LITERATURE CITED}

Anderson, R. S., Haff, P. K. (1988). Simulation of eolian saltation. Science 241: 820-823

Bagnold, R. A. (1954). Experiments on a gravity-free dispersion of large solid spheres in a Newtonian fluid under shear. Proc. R. Soc. Lond. 225: 49-63

Bagnold, R. A. (1956). The flow of cohesionless grains in fluids. Phil. Trans. R. Soc. 249 A. 235-297

Bagnold, R. A. (1966). An approach to the sediment transport problem from general physics. U.S. Geological Survey Prof. Pap. 422-I, Washington, D.C.

Beach, R. A., Sternberg, R. W. (1988). Suspended sediment transport in the surf zone: response to cross-shore infragravity motion. Mar. Geol. 80: 61-79

Cammen, L. M. (1982). Effect of particle size on organic content and microbial abundance within four marine sediments. Mar. Ecol. Prog. Ser. 9: 273-280

Cammen, L. M., Walker, J. A. (1986). The relationship between bacteria and micro-algae in the sediment of a Bay of Fundy mudflat. Estuar. coast. Shelf Sci. 22: 91-99

Chambers, J. M., Cleveland, W. S., Kleiner, B., Tukey, P. A (1983). Graphical methods for data analysis. Wadsworth International Group, Belmont, California

Charters, A. C., Neushul, M., Coon, D. (1973). The effect of water motion on algal spore adhesion. Limnol. Oceanogr 18: 884-896

Dale, N. G. (1974). Bacteria in intertidal sediments: factors related to their distribution. Limnol. Oceanogr 19: 509-518

DeFlaun, M. F., Mayer, L. M. (1983). Relationships between bacteria and grain surfaces in intertidal sediments. Limnol. Oceanogr. 28: 873-881

Downing, J. P., Jr. (1983). Field studies of suspended sand transport, Twin Harbors Beach, Washington. Ph.D. dissertation, Univ. of Washington, Seattle

Eckman, J. E. (1985). Flow disruption by an animal-tube mimic affects sediment bacterial colonization. J. mar. Res. 43: 419-435

Fielding, P. J., Damstra, K. St. J., Branch, G. M. (1988). Benthic diatom biomass, production and sediment chlorophyll in Langebaan Lagoon, South Africa. Estuar. coast. Shelf Sci. 27: 413-426

Froment, G. F., Bischoff, K. B. (1979). Chemical reactor analysis and design. John Wiley \& Sons, New York

Grant, J. (1983). The relative magnitude of biological and physical sediment reworking in an intertidal community. J. mar. Res. 41: 673-689

Grant, J. (1986). Sensitivity of benthic community respiration and primary production to changes in temperature and light. Mar. Biol. 90: 299-306

Grant, J., Bathmann, U. V., Mills, E. L. (1986). The interaction between benthic diatom films and sediment transport. Estuar. coast. Shelf Sci. 23: 225-238

Grant, W. D., Boyer, L. F., Sanford, L. P. (1982). The effect of biological processes on the initiation of sediment motion in non-cohesive sediments. J. mar. Res. 40: 659-677 
Grant, W. D., Madsen, O. S. (1982). Movable bed roughness in unsteady oscillatory flow. J. geophys. Res. 87: 469-481

Hanes, D. M., Inman, D. L. (1985). Observations of rapidly flowing granular-fluid materials. J. Fluid Mech. 150: $357-380$

Hobbie, J. E., Daley, R. J., Jasper, S. (1977). Use of Nuclepore filters for counting bacteria by fluorescence microscopy. Appl. environ. Microbiol. 33: 1225-1228

Hollander, M., Wolfe, D. A. (1973). Nonparametric statistical methods. John Wiley \& Sons, New York

Höpner, T., Wonneberger, K. (1985). Examination of the connection between the patchiness of benthic nutrient efflux and epiphytobenthos patchiness on intertidal flats. Neth. J. Sea Res. 19: 277-285

Jenkins, J. T., Savage, S. B. (1983). A theory for the rapid flow of identical, smooth, nearly elastic, spherical particles. J. Fluid Mech. 130: 187-202

Jonge, V. N. de (1985). The occurance of 'epipsammic' diatom populations: a result of interaction between physical sorting of sediment and certain properties of diatom species. Estuar. coast. Shelf Sci. 21: 607-622

Jonge, V N. de, Bergs, J. van der (1987). Experiment on the resuspension of estuarine sediments containing benthic diatoms. Estuar. coast. Shelf Sci. 24: 725-740

Kachel, N. B., Smith, J. D. (1986). Geologic impact of sediment transporting events on the Washington Continental shelf. In: Knight, R. J. (ed.) Shelf sands and sandstones. Can. Assoc. Petrol. Geol. Mem. II, p. 145-162

Kachel, N. B., Sternberg, R. W. (1971). Transport of bedload as ripples during an ebb current. Mar. Geol. 19: 229-244

Kobayashi, N., Seo, S. N. (1985). Fluid and sediment interaction over a plane bed. J. Hydraulic Eng. 111. 903-921

Kobayashi, N., DeSilva, G. S. (1987). Motion of sediment particles in swash zone. In: Dalrymple, R. A. (ed.) Coastal hydrodynamics. Proceedings of a conference. American Society of Civil Engineers, New York, p. 715-730

Lukatelich, R. J., McComb, A. J. (1986). Distribution and abundance of benthic microalgae in a shallow southwestern Australia estuarine system. Mar. Ecol. Prog. Ser 27: 287-297

Meadows, P. S., Anderson, J. G. (1968). Micro-organisms attached to marine sand grains. J. mar. biol. Ass. U.K. 48: 161-175

Meyer-Reil, L.-A., Dawson, R., Liebezeit, G., Tiedge, H. (1978). Fluctuations and interactions of bacterial activity in sandy beach sediments and overlying waters. Mar Biol. 48: $161-171$

Miller, D. C. (1985). Interactions of marine sediment transport with deposit feeding and microbial growth. Ph.D. dissertation, Univ. of Washington, Seattle

Miller, D. C., Jumars, P. A., Nowell, A. R. M. (1984). Effects of sediment transport on deposit feeding: scaling arguments. Limnol. Oceanogr. 29: 1202-1217

Miller, D. C., Sternberg, R. W (1988). Field measurements of the fluid and sediment-dynamic environment of a benthic deposit feeder. J. mar. Res. 46: 771-796

Montagna, P. A. (1982). Sampling design and enumeration statistics for bacteria extracted from marine sediments. Appl.. environ. Microbiol. 43: 1366-1372

Munro, A. L. S., Wells, J. B. J., McIntyre, A. D. (1978). Energy flow in the flora and meiofauna of sandy beaches. Proc. R. Soc. Edinb. 76 B: 297--315

N.O.A.A. (1984). Tide tables 1985. West coast of North

This article was presented by Professor G. Rheinheimer, Kiel, FR Germany
America and South America. U.S. Dept. Commerce Washington, D.C.

Nowell, A. R. M., Jumars, P. A., Eckman, J. E. (1981). Effects of biological activity on the entrainment of marine sediments Mar. Geol. 42: 133-153

Pamatmat, M. M. (1968). Ecology and metabolism of a benthic community on an intertidal sandflat. Int. Rev. ges. Hydrobiol. 53: 211-298

Plante, R., Plante-Cuny, M.-R., Reys, J.-P. (1986). Photosynthetic pigments of sandy sediments on the north Mediterranean coast: their spatial distribution and its effect on sampling strategies. Mar. Ecol. Prog. Ser. 34: $133-141$

Plante-Cuny, M.-R., Bodoy, A. (1987). Biomasse et production primaire du phytoplancton et du microphytobenthos de deux biotopes sableux (Golfe de Fos. France). Oceanologica Acta 10: 223-237

Rao, V N. R., Lewin, J. (1976). Benthic marine diatom flora of False Bay, San Juan Island, Washington. Syesis 9: 173-213

Savage, S. B., Jeffrey, D. J. (1981). The stress tensor in a granular flow at high shear rates. J. Fluid Mech. 110: $255-272$

Savage, S. B., Sayed, M. (1984). Stresses developed by dry cohesionless granular materials sheared in a annular shear cell. J. Fluid Mech. 142: 391-430

Shaffer, G. P. (1988). A comparison of benthic microfloral production on the west and Gulf coasts of the United States: an introduction to the dynamic K-systems model Mar. Ecol. Prog. Ser. 43: 55-62

Sokal, R. R., Rohlf, F. J. (1981). Biometry. 2nd edn. Freeman

Steele, J., Baird, I. E. (1968). Production ecology of a sandy beach. Limnol. Oceanogr. 13: 14-25

Steele, J. H., Munro, A. L. S., Giese, G. S. (1970). Environmental factors controlling the epipsammic flora on beach and sublittoral sands. J. mar. biol. Ass. U.K. 50: 907-918

Sternberg, R. W., Larsen, L. H., Miao, Y. T (1985). Tidally driven sediment transport on the East China Sea continental shelf. Cont. Shelf Res. 4: 105-120

Stevenson, R. J. (1986). Importance of variation in algal immigration and growth rates estimated by modelling benthic algal colonization. In: Evans, L. V., Hoagland K. D. (eds.) Algal biofouling. Studies in environmental science 28. Elsevier, Amsterdam, p. 193-210

Sundbäck, K., Jönsson, B. (1988). Microphytobenthic productivity and biomass in sublittoral sediment of a stratified bay, southeastern Kattegat. J. exp. mar. Biol. Ecol. 122 $63-81$

Taghon, G. L., Nowell, A. R. M., Jumars, P. A. (1984). Transport and breakdown of fecal pellets: biological and sedimentological consequences. Limnol. Oceanogr. 29: $752-759$

Tanaka, N. (1986). Adhesive strength of epiphytic diatoms on various seaweeds. Bull. Jap. Soc scient. Fish. 52: 817-821

Vincent, C. E., Young, R. A., Swift, D. J. P. (1982). On the relationship between bedload and suspended sand transport on the inner shelf, Long Island, New York. J. geophvs. Res. 87: 4163-4170

Weise, W. Rheinheimer, G. (1978). Scanning electron microscopy and epifluorescence investigations of bacterial colonization of marine sand sediments. Microbial Ecol. 4: $175-178$

Wiberg, P. L., Smith, J. D. (1985). A theoretical model for saltating grains in water. J. geophys. Res. 90: 7341-7354

Manuscript first received: December 16, 1985

Revised version accepted: April 3, 1989 